\title{
Combining Ability Studies for Fiber Quality Traits in Desi Cotton (Gossipium Arboreum L.)
}

\author{
R. Divya Bandhavi ${ }^{1 *}$, H.V. Kalpande ${ }^{1}, \operatorname{Rashad}_{\text {Khan }}{ }^{2}$ and Siddarth Panda $^{2}$ \\ ${ }^{1}$ Department of Agricultural Botany, Vasantrao Naik Marathwada Krishi Vidyapeeth, \\ Parbhani-431402, Maharashtra, India \\ ${ }^{2}$ Department of Plant Breeding and Genetics, OUAT, Bhubaneshwar, Odisha, India \\ *Corresponding author
}

\begin{abstract}
Keywords
Cotton, Fiber quality, GCA, SCA, Line $\mathrm{x}$ tester analysis

Article Info

Accepted:

07 February 2019

Available Online:

10 March 2019 743, PA 734, PA760, PA 720, PAIG 326) with four arboreum testers (PA 255, PA 402, PA 08, PA 528) were tested along with their parents including two checks (PKVDH 1, SWADESHI 651). The observations on five fiber quality traits were recorded on randomly selected five plants. Among ten parental lines, four lines were found to be the best general combiners. PA 760 and PA 255 showed good general combiner for 2.5 per cent span length, PA 743, PA 734, PA 08, PA 255 showed good general combiner for fibre fineness (micronaire) and PA 720 and PA 760 among females and PA 255 in males showed good gca for short fibre index and fibre strength. Likewise PAIG 326 and PA 720 showed same for uniformity ratio in desirable direction. The study of sca revealed that the cross PA 734 x PA 528 exhibited significant high sca effect for 2.5 per cent span length, fiber strength and showed significant negative sca effect for short fibre index. Whereas the cross PA 760 x PA 402 exhibited positive significant sca effects for fibre strength and uniformity ratio. Similarly the crosses PAIG 326 x PA 255 and PA 734 x PA 528 showed significant negative sca effect for short fibre index.
\end{abstract}

\section{A B S T R A C T}

Twenty four hybrid combinations derived by crossing six arboreum lines (PA 713, PA

\section{Introduction}

Cotton the 'white gold' enjoys a pre-eminent status among all cash crops in the country. It is grown commercially in the temperate and tropical regions of more than 70 countries. Currently, Gossypium includes 50 species, four of which are cultivated, 43 are wild diploids and three are wild tetraploid. Out of the four cultivated species, Gossypium hirsutum L. and Gossypium barbadense L., commonly called as new world cottons are tetraploids $(2 \mathrm{n}=4 \mathrm{x}=52)$, whereas, Gossypium herbaceum L. and Gossypium arboreum $\mathrm{L}$. are diploids $(2 \mathrm{n}=2 \mathrm{x}=26)$ and are commonly called as old world cottons. Out of four cultivated species of genus Gossypium, only two species i.e. G. hirsutum and G. arboreum are being mostly cultivated in Maharashtra. G. arboreum, also known as Tree Cotton, together provide $2 \%$ of the world's cotton. In the last few years there has been a significant reduction in area of $G$. arboreum cotton across the country and 
particularly in Maharashtra because of lower productivity and inferior fibre properties as compared to tetraploid cotton in rainfed ecosystem and non availability of Bt variety / hybrid. Genetic improvement in desi cotton could be gain either through combination or exploitation of hybrid vigour. Although, Indian cottons have very wide quality spectrum, the right combination of fibre length, micronaire and fibre strength is however absent in many of the popular varieties and hybrids. The deficiency in particularly discernable in the staple range of 27 to $30 \mathrm{~mm}$ combined with micronaire of 4.0 to 4.5 and a strength of 22 to $25 \mathrm{~g}$ per tex. Indian cottons confirming to long and extra long staple group are too fine coupled with weak strength. There is an urgent need to promote those cottons that could come closer in quality to the most sought by modern textile mills. The information on the nature and magnitude of gene action is important in understanding the genetic potential of population and decide the breeding procedure to be adopted in given population. Line $\mathrm{x}$ tester analysis is a precise method for obtaining such information when a large number of parents to be tested.

\section{Materials and Methods}

The present investigation was undertaken to study "combining ability studies for fiber quality traits in desi cotton (Gossypium arboreum L.)" in line $\mathrm{x}$ tester programme involving twenty four hybrid combinations derived by crossing six arboreum lines(PA 713, PA 743, PA 734, PA760, PA 720, PAIG 326) with four arboreum testers(PA 255, PA 402, PA 08, PA 528) were tested along with their parents including 2 checks (PKVDH 1, SWADESHI 651) at Cotton Research Station, Mahboob Baugh farm, Vasantrao Naik Marathwada Krishi Vidyapeeth, Parbhani during kharif season of 2013-14. All the parental material was planted during summer
2013. Two sets of parental lines were sown at an interval of 8 days to ensure synchrony in flowering and to complete hybridization between selected parents. The line $\mathrm{x}$ tester $(6 \mathrm{x}$ 4) crossing was effected and total 24 crosses along with ten parents and 2 checks were grown in randomized block design with three replications with spacing of $60 \mathrm{~cm} X 30 \mathrm{~cm}$. Observations were recorded on the following fiber quality components $2.5 \%$ span length $(\mathrm{mm})$, Micronaire/Fibre fineness $\left(10^{-6} \mathrm{~g} / \mathrm{inch}\right)$, Fibre strength (g/tex), Uniformity ratio (\%), Short fiber index $(\%)$.

\section{Results and Discussion}

The cross PA 743 x PA 528 (1.92), PA 713 x PA 528 (1.75) and PAIG 326 x PA 255 (1.72) showed significant positive SCA effects for $2.5 \%$ span length. Out of 24 crosses the cross PA $760 \times$ PA 402 (2.19), PAIG 326 x PA 08 (1.29) and PA 713 x PA 528 (1.22) showed significant positive SCA effects for fiber strength. The cross PA 760 x PA 402 (2.08) exhibited positive significant SCA effects for uniformity ratio. For Short fibre index (\%) Out of twenty four crosses studied, six crosses showed significant positive SCA effects and five crosses exhibited negative significant effects. The cross PAIG 326 x PA 528 (6.02) followed by PAIG 326 x PA 402 (2.62) showed maximum significant positive SCA effects. While cross PAIG 326 x PA 255 (5.45) exhibited maximum significant negative SCA effects, followed by PA 743 x PA 528 (3.58), PAIG 326 x PA 08 (-3.18), PA 760 x PA $402(-2.83)$ and PA 713 x PA $528(-2.60)$ (Table 3).

Analysis of variances due to gca $\left(6^{2}\right.$ gca) were relatively lower in magnitude as compared to sca variances $\left(\sigma^{2}\right.$ sca) (Table 1$)$. The ratio of $\sigma^{2} \mathrm{gca} / \sigma^{2} \mathrm{sca}$ was less than unity for most of the characters indicating predominance of non-additive gene action. These components can be exploited by heterotic breeding 
programme Preetha and Ravindran (2008) and Deosarkar et al., (2009) also reported non additive type of gene action for these traits.

The female parent, PA 743 exhibited highest 2.5 per cent span length $(28.20 \mathrm{~mm})$ whereas; the PA 713 and PA 720 had recorded lowest length $(26.30 \mathrm{~mm})$. Among male parents, PA 08 exhibited highest span length with 26.00 $\mathrm{mm}$, while PA 402 had recorded lowest 2.5 per cent span length $(24.00 \mathrm{~mm})$ (Table 2.1). The mean values for hybrids were ranged from $28.60 \mathrm{~mm}$ (PA $760 \times$ PA 255) to 21.70 $\mathrm{mm}$ (PAIG 326 x PA-520). In remaining crosses the highest 2.5 per cent span length was recorded by the cross PA 743 x PA 255 and PA 760 x PA $08(28.40 \mathrm{~mm})$ followed by PA 734 x PA $528(28.20 \mathrm{~mm})$, PA 713 x PA $528(27.90 \mathrm{~mm})$, PA $720 \times$ PA 255 and PA 720 x PA $08(27.80 \mathrm{~mm})$. Twenty two hybrids were exhibiting higher than the standard check PKVDH 1 (24.70). Low micronaire value is desirable fibre trait which indicates fibre fineness. The female parental line, PA 720 (5.20 $\mu \mathrm{g} / \mathrm{inch})$ had recorded lowest micronaire value. Whereas, male parent PA 255, PA 402 and PA 528 are exhibited lowest micronaire value $5.9 \mu \mathrm{g} / \mathrm{inch}$. Among the hybrids PA 760 $x$ PA 08 had recorded lowest micronaire value (5.20 $\mu \mathrm{g} /$ inch) followed by PA 743 x PA 255 and PA 760 X PA 255 (5.30 $\mu \mathrm{g} / \mathrm{inch})$, PA 743 x PA $08(5.40 \mu \mathrm{g} / \mathrm{inch})$ and PA 713 x PA 08 (5.50 $\mu \mathrm{g} / \mathrm{inch})$. Twenty two hybrids reported lowest micronaire and negatively significant over check PKVDH 1(6.40 $\mu \mathrm{g} /$ inch $)$ and none over Swadeshi- 615 (7.00 $\mu \mathrm{g} / \mathrm{inch})$.

Fibre strength (g/tex) is most important fibre character. Cotton breeder is always searching high fibre strength material. Mean values of the female parents for fibre strength was ranged from 20.50 (PA 743) to $16.90 \mathrm{~g} / \mathrm{tex}$ (PA 713). While for male fibre strength was ranged from 17.30 (PA 255) to $21.00 \mathrm{~g} /$ tex (PA 08). Mean performance of the hybrids for fibre strength was ranged from 16.70 (PA 713 $x$ PA 402) to $21.20 \mathrm{~g} /$ tex (PA 720 x PA 255). The hybrids, PA 760 x PA 402 (21.10 g/tex), PA $760 x$ PA 255(20.40g/tex), and PAIG 326 x PA 08 (19.80 g/tex) were recorded highest fibre strength. Twenty two hybrids exhibited higher fibre strength than Swadeshi-615 (17.00). The highest mean value of uniformity ratio in female parents was $49.00 \%$ (PA 713). Whereas, it was lowest in PA 760 and PA 743 $(47.00 \%)$. The mean value of uniformity ratio for male parents was highest for PA 402 (51.00\%). Whereas, it was lowest in PA 255 and PA 528 (47.00\%). The hybrid PAIG $326 \mathrm{x}$ PA $528(53.00 \%)$ had recorded highest value and lowest values of uniformity ratio for PA 760 XPA 08 (47.00\%). Among the hybrids maximum value of uniformity ratio was noticed $52.00 \%$ (PA $760 \times$ PA 402, PA 720 x PA 08, PA 720 x PA 528 and PAIG 326 x PA 528). Ten hybrids showed highest value of uniformity ratio over the check PKVDH 1. Low short fibre index value is desirable fibre trait which decreasing the waste loss during processing and cause evenness and increasing yarn strength. The female parental line, PA $743(8.10 \%)$ had recorded lowest short fibre index value. Whereas, Male parent PA 08 $(11.70 \%)$ exhibited lowest short fibre index value. Among the hybrids PA 734 x PA-520 and PA $720 \times$ PA 08 had recorded lowest short fibre index value $(7.60 \%)$ followed by PA $760 \times$ PA 402 (7.90\%) and PA $760 \times$ PA 255 (8.40\%). Two hybrids exhibited higher short fibre index than the standard checks Swadeshi-615 (15.10). After comparison of heterotic crosses and their per se performance for various characters, it was observed that the crosses showing high heterosis and high per se performance involved the parents possessing either high $\mathrm{x}$ high, high $\mathrm{x}$ low and low $\mathrm{x}$ low combining ability parents indicating importance of non additive genetic variance. Among ten parental lines, four lines were found to be the best general combiner which had significant GCA effects for fibre quality traits (Table 1-3). 
Table.1 Analysis of variance for Randomized Block Design

\begin{tabular}{|c|c|c|c|c|c|c|}
\hline Source & d.f. & $\begin{array}{c}\mathbf{2 . 5 \%} \mathbf{S L} \\
\text { length }(\boldsymbol{\%})\end{array}$ & $\begin{array}{c}\text { Fibre fineness } \\
\text { (Micronaire) } \\
(\boldsymbol{\mu g} / \mathbf{i n c h})\end{array}$ & $\begin{array}{c}\text { Fibre } \\
\text { strength } \\
(\mathbf{g} / \text { tex })\end{array}$ & $\begin{array}{c}\text { Uniformity } \\
\text { ratio }(\boldsymbol{\%})\end{array}$ & $\begin{array}{c}\text { Short fibre } \\
\text { index }(\boldsymbol{\%})\end{array}$ \\
\hline Replications & 2 & 0.1052 & 0.0069 & 0.10027 & 0.111 \\
\hline Treatments & 35 & $9.0917^{* *}$ & $0.7474^{* *}$ & $5.1195^{* *}$ & $9.0547^{* *}$ & $31.2094^{* *}$ \\
\hline Error & 70 & 0.9978 & 0.115 & 0.6837 & 2.911 & 2.0566 \\
\hline
\end{tabular}

* Significant 5 per cent level

** Significant 1 per cent level

Table.2.1 General combining ability effects (GCA) for lines

\begin{tabular}{|c|c|c|c|c|c|}
\hline Parents & $\begin{array}{c}\mathbf{2 . 5 \%} \mathbf{S L} \\
\text { length } \mathbf{( m m})\end{array}$ & $\begin{array}{c}\text { Fibre fineness } \\
\text { (Micronaire) } \\
(\boldsymbol{\mu g} / \mathbf{i n c h})\end{array}$ & $\begin{array}{c}\text { Fibre } \\
\text { strength } \\
(\mathbf{g} / \mathbf{t e x})\end{array}$ & $\begin{array}{c}\text { Uniformity ratio } \\
\mathbf{( \% )}\end{array}$ & $\begin{array}{c}\text { Short fibre } \\
\text { index }(\boldsymbol{\%})\end{array}$ \\
\hline PA 713 & 0.046 & 0.062 & $-0.729^{* *}$ & -0.66 & -0.292 \\
\hline PA 743 & 0.521 & $-0.263^{*}$ & $-0.604^{*}$ & $-1.167^{*}$ & $-1.092^{*}$ \\
\hline PA 734 & 0.171 & $-0.238^{*}$ & -0.279 & -0.417 & -0.617 \\
\hline PA 760 & $0.671^{*}$ & -0.188 & $0.546^{*}$ & -0.417 & $-0.867^{*}$ \\
\hline PA 720 & 0.496 & -0.063 & $1.046^{* *}$ & $1.083^{*}$ & $-1.917^{* *}$ \\
\hline PAIG 326 & $-1.904^{* *}$ & $0.688^{* *}$ & 0.021 & $1.583^{* *}$ & $4.783^{* *}$ \\
\hline S.E.(Gi) & 0.294 & 0.099 & 0.244 & 0.495 & 0.423 \\
\hline S.E.(Gi-Gj) & 0.416 & 0.141 & 0.345 & 0.699 & 0.598 \\
\hline CD @ 5\% & 0.592 & 0.200 & 0.492 & 0.996 & 0.851 \\
\hline CD @ 1\% & 0.790 & 0.267 & 0.656 & 1.329 & 1.136 \\
\hline
\end{tabular}

*and ** indicated significance at 5 and 1 per cent respectively. 
Table.2.2 General combining ability effects (GCA) for testars

\begin{tabular}{|c|c|c|c|c|c|}
\hline Parents & $\begin{array}{l}2.5 \% \text { SL lenth } \\
(\mathrm{mm})\end{array}$ & $\begin{array}{c}\text { Fibre fineness } \\
\text { (Micronaire) } \\
\text { ( } \mu \text { g/inch) }\end{array}$ & $\begin{array}{l}\text { Fibre strength } \\
\qquad(\mathrm{g} / \mathrm{tex})\end{array}$ & $\begin{array}{l}\text { Uniformity ratio } \\
\qquad(\%)\end{array}$ & $\begin{array}{l}\text { Short fibre } \\
\text { index }(\%)\end{array}$ \\
\hline PA 255 & $1.029 * *$ & -0.129 & $0.613 * *$ & 0.167 & $-1.375 * *$ \\
\hline PA 402 & $-0.771 * *$ & $0.171 *$ & -0.288 & 0.167 & $0.958 * *$ \\
\hline PA 08 & 0.296 & $-0.213^{*}$ & -0.171 & -0.333 & $-0.742 *$ \\
\hline PA 528 & $-0.554 *$ & $0.171 *$ & -0.154 & 0.000 & $1.158 * *$ \\
\hline S.E.(Gi) & 0.240 & 0.081 & 0.199 & 0.404 & 0.345 \\
\hline S.E.(Gi-Gj) & 0.340 & 0.115 & 0.282 & 0.571 & 0.488 \\
\hline CD@5\% & 0.483 & 0.163 & 0.401 & 0.813 & 0.695 \\
\hline CD@1\% & 0.645 & 0.218 & 0.536 & 1.085 & 0.927 \\
\hline
\end{tabular}

* Significant 5 per cent level; ** Significant 1 per cent level

Table.3 Specific combining ability effects (SCA) for hybrids

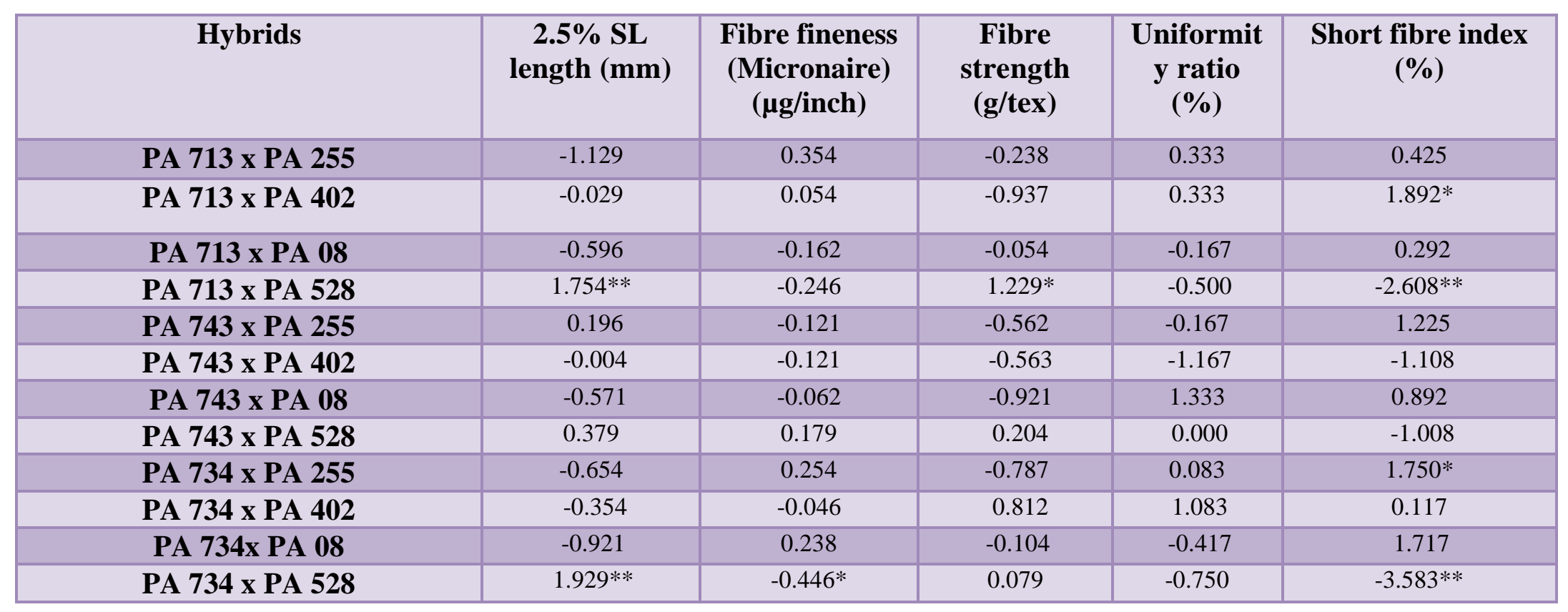


Contd....

\begin{tabular}{|c|c|c|c|c|c|}
\hline Hybrids & $\begin{array}{c}\mathbf{2 . 5 \%} \text { SL } \\
\text { length }(\mathbf{m m})\end{array}$ & $\begin{array}{c}\text { Fibre fineness } \\
(\text { Micronaire }) \\
(\boldsymbol{\mu g} / \mathbf{i n c h})\end{array}$ & $\begin{array}{c}\text { Fibre } \\
\text { strength } \\
(\mathbf{g} / \mathbf{t e x})\end{array}$ & $\begin{array}{c}\text { Uniformity } \\
\text { ratio }(\boldsymbol{\%})\end{array}$ & $\begin{array}{c}\text { Short fibre index } \\
(\%)\end{array}$ \\
\hline PA 760 x PA 255 & 0.246 & -0.196 & 0.587 & 1.083 & 0.000 \\
\hline PA 760 x PA 402 & 0.846 & 0.204 & $2.188^{* *}$ & $2.083^{*}$ & $-2.833^{* *}$ \\
\hline PA 760 x PA 08 & 0.779 & -0.213 & $-1.729^{* *}$ & $-2.417^{*}$ & 0.667 \\
\hline PA 760 x PA 528 & $-1.871^{* *}$ & 0.204 & $-1.046^{*}$ & -0.750 & $2.167^{*}$ \\
\hline PA 720 x PA 255 & -0.379 & 0.079 & 0.888 & -0.417 & $2.050^{*}$ \\
\hline PA 720x PA 402 & -0.279 & -0.221 & -0.113 & -1.417 & -0.683 \\
\hline PA 720x X PA 08 & 0.354 & 0.163 & -0.329 & 1.083 & -0.383 \\
\hline PA 720x x PA 528 & 0.304 & -0.021 & -0.446 & 0.750 & -0.983 \\
\hline PAIG 326 x PA 255 & $1.721^{* *}$ & -0.371 & 0.112 & -0.917 & $-5.450^{* *}$ \\
\hline PAIG 326 x PA 402 & -0.179 & 0.129 & $-1.388^{* *}$ & -0.917 & $2.617^{* *}$ \\
\hline PAIG 326 x PA 528 & -2.954 & -0.088 & $1.296^{*}$ & 0.583 & $-3.183^{* *}$ \\
\hline S.E. \pm & 0.577 & 0.329 & -0.021 & 1.250 & $6.017^{* *}$ \\
\hline
\end{tabular}


PA 760 for $2.5 \%$ span length, PA 743 for fibre fineness (micronaire), PA 720 for fibre strength, PAIG 326 for uniformity ratio and PA 720 for short fibre index showed good general combining ability these can be utilized for further hybridization programmes. PA 734 x PA 528 for $2.5 \%$ span length and fibre fineness, PA $760 \times$ PA 402 for fibre strength and uniformity ratio and PAIG $326 \times$ PA 255 for short fibre index showed good sca effects, these crosses will be exploited for commercially after multilocation testing.

\section{References}

Ahuja, S.L. and Dhayal, L.S. 2007. Combining ability estimates for yield and fibre quality traits in $4 \times 13$ line $x$ tester crosses of Gossypium hirsutum. Euphytica., 153 1/2: 87-98.

Anandan, A. 2010. Environmental impact on the combining ability of fiber traits and seed cotton yield in cotton. J. Crop Improv., 24 (4): 310-323.

Basal, H., Canavar, O., Khan, N. U. and Cerit, C. S. 2011. Combining ability and heterotic studies through line $\mathrm{x}$ tester in local and exotic upland cotton genotypes. Pakistan J. Bot., 43 (3): 1699-1706.

DaiGang Yang, Ma XiongFeng, Zhou XiaoJian, Zhang XianLiang, Bai FengHu, Wang HaiFeng, Meng QingQin, Pei XiaoYu and $\mathrm{Yu}$ ShuXun. 2012. Correlation among combining ability, heterosis and genetic distance in upland cotton. [Chinese] Cotton Sci., 24 (3): 191-198.

Deosarkar, D. B. Jadhav, D. S. and Patil, S. G. 2009. Combining ability studies for yield and quality traits in cotton (Gossypium hirsutum L.). J. Cotton Res. Dev., 23 (2): 183-187.

Jatoi, W.A., Baloch, M. J., Veesar, N. F. and Panhwar, S. A. 2011.Combining ability estimates from line $\mathrm{x}$ testar analysis for yield and yield components in upland cotton genotypes. J. Agri. Res., 49(2): 165172.

Kumar A. 2014. Heterosis and combining ability for yield and fibre quality in desi cotton (Gossypium arboreum L.). M.Sc. Thesis submitted to V.N.M.K.V. Parbhani.

Manickam, S. and Gururajan, K. N. (2004).Combining ability analysis for fiber quality in upland cotton. J. Indian Soc. Cotton Improv. 6: 86-91.

Mendez-Natera, J. R., Rondon, A., Hernandez, J. and Merazo-Pinto, J. F. 2012. Genetic studies in upland cotton ( $G$. hirsutum L.) II. General and specific combining ability. $J$. Agri. Sci. and Tech., 14 (3): 617-627.

Nidagundi, J. M., Deshpande, S. K., Patil, B. R. and Mane, R. S. 2011. Combining ability and heterosis for yield and fiber quality traits in American cotton. Crop Improv.,38 (2): 179-185.

Preetha, S. and T.S. Raveendran (2008). Combining ability and heterosis for yield and fibre quality traits in line $\mathrm{X}$ testers crosses of upland cotton ( $G$. hirsutum L.) International Journal of Plant Breeding and Genetics 2(2): 64-74.

Reddy, C.V.C.M. and Reddy Y. R. (2011). Genetic parameters for yield and fibre quality traits in desi cotton (Gossypium arboreum L.). Journal of Cotton Research and Development, 25: 2, 168-170. 9 ref.

Sandip, A., Patil M.R., Naik G.R., Chougule V.D., Pathak and Atul B.Patil,( 2012). Combining ability analysis for yield and fibre quality traits in upland cotton (Gossypium hirsutum L.).

Shimna Bhaskaran, Ravikesavan R.,(2008) Combining ability analysis of tield related trait and fiber quality traits in cotton (Gossypium sp.) Journal of Cotton Research and Development. 22: 1, 23-27.

\section{How to cite this article:}

Divya Bandhavi, R., H.V. Kalpande, Rashad Khan and Siddarth Panda. 2019. Combining Ability Studies for Fiber Quality Traits in Desi Cotton (Gossipium Arboreum L.). Int.J.Curr.Microbiol.App.Sci. 8(03): 415-421. doi: https://doi.org/10.20546/ijcmas.2019.803.052 